Missio Ecclesiae
ISSN 2086-5368 (Print)
ISSN 2086-5368 (Online)
https://jurnal.i3batu.ac.id/index.php/me
Vol.10, No.2, pp. 155-168, 2021

\title{
Kajian Teologis Terhadap Status Perempuan Dalam Perjanjian Baru
}

\author{
Iwan Setiawan ${ }^{a}$, Martono $^{b}$, Yulia Vriska Tripena ${ }^{c}$, Chresty Thessy \\ Tupamahu ${ }^{d}$ \\ $a^{*}$ Institut Injil Indonesia, jenny.iwan08@gmail.com \\ ${ }^{b}$ Gereja Kristen Alkitab Indonesia, martono2702@gmail.com \\ ${ }^{c}$ Gereja Persekutuan Pemberitaan Injil Kristus, priskatri17@gmail.com \\ ${ }^{d}$ Institut Injil Indonesia, chresttupamahu@gmail.com
}

\begin{tabular}{l}
\hline INFO ARTIKEL \\
\hline Sejarah Artikel: \\
Diterima: Oktober 2021 \\
Direvisi: Oktober 2021 \\
Disetujui: Oktober \\
2021 \\
Dipublikasi: Oktober \\
2021 \\
\hline
\end{tabular}

Kata Kunci:

Kajian Teologis, Status Perempuan, Perjanjian Baru.

\section{Keywords:}

Theological Studies, Status of Women, New Testament.

\begin{abstract}
ABSTRAK
Allah menjadikan perempuan supaya menjadi penolong bagi seorang laki-laki bukan menjadi kenikmatan para lelaki. Sikap ajaran Yesus tentu sangat berbeda dengan ajaran Yudaisme tentang perempuan pada jaman Yesus masih hidup. Kaum lakilaki yang kurang menghormati kaum perempuan banyak mendominasi ajaran Yudaisme. Besarnya perbedaan di antara keduanya menyebabkan perempuan tidak dapat memiliki kedudukan yang setaraf dalam pendidikan agama atau dalam ibadah. Penelitian ini bertujuan untuk mendapatkan pemahaman secara teologis mengenai status perempuan dalam Perjanjian Baru. Penelitian ini menggunakan pendekatan kualitatif dengan cara mengumpulkan data kepustakaan yang berasal dari artikel jurnal maupun buku-buku untuk mengekspos status perempuan dalam Perjanjian Baru. Berdasarkan hasil penelitian ditemukan bahwa perempuan diakui harkat dan martabatnya, bahkan perempuan menjadi rekan kerja Yesus di sepanjang pelayanan-Nya. Demikian pula dalam pelayanan Paulus, perempuan terlibat menjadi rekan kerja, sehingga tidak dapat disangkal bahwa perempuan juga dapat mengambil peran dan kedudukan penting di gereja dengan porsi masing-masing. Dalam Perjanjian Baru bagi orang Yahudi perempuan adalah kaum yang lemah, sehingga tindakan mereka dibatasi, hak dan kewajiban serta perannya juga dikurangi bahkan tidak jarang perempuan juga diperbudak dan diperlakukan secara tidak adil. Tetapi Yesus Kristus hadir untuk membawa perubahan yang besar bagi kaum marginal termasuk perempuan, yaitu pembebasan dari belenggu dan sikap diskriminatif. Kini mereka diberikan hak dan kesempatan yang sama untuk melakukan hal-hal positif termasuk kesempatan untuk melayani Tuhan.
\end{abstract}




\begin{abstract}
God made women to be a helper for a man, not a pleasure for men. The attitude of Jesus' teachings about women is very different from the teachings of Judaism about women at the time Jesus lived on earth. Judaism is dominated by men who have little respect for women. The difference between men and women is so great that women cannot equal with men, whether in religion education or worship. This study aims to gain a theological understanding of the status of women in the New Testament. This study uses a qualitative method by collecting bibliographical data from both books and journals to expose the status of women in the New Testament. Based on the results of the study, it was found that women were recognized for their worth and dignity, even women became Jesus' co-workers throughout His ministry. Apostle Paul also included women as his partners in ministry so it cannot be denied that women can also take on very important roles and positions in the church with their respective portions. The Jews in the New Testament view women as the weak so that their actions are limited, their rights and obligations and their roles are also reduced and it is not uncommon for women to be enslaved and treated unfairly. But, Jesus Christ is here to bring a big change for the marginalized, including women, namely liberation from shackles and discriminatory attitudes. Now they are given the same rights and opportunities to do positive things including the opportunity to serve God.
\end{abstract}

\title{
PENDAHULUAN
}

Perempuan adalah pribadi yang unik dan istimewa. Ia bisa menjadi teman cerita bagi kaum pria. Perempuan juga mempunyai peran yang sangat istimewa dan penting di dalam kehidupan keluarga. Perempuan adalah sosok yang selalu dinantikan oleh seorang pria. Allah menjadikan perempuan supaya menjadi penolong bagi seorang laki-laki bukan menjadi kenikmatan para lelaki.

Sikap ajaran Yesus tentang perempuan jika dibandingkan dengan sikap ajaran Yudaisme tentang perempuan pada masa Yesus hidup di dunia sangatlah berbeda. Ajaran Yudaisme didominasi oleh kaum pria yang bersikap tidak menghargai wanita. Laki-laki dan perempuan dipandang secara berbeda sehingga kaum perempuan tidak dapat memiliki kesetaraan baik dalam pendidikan agama ataupun ibadah. Beberapa kalangan orang kafir menganggap perempuan lebih rendah dari laki-laki. Pengajaran Yesus tidak hanya berfokus pada misi-Nya, namun juga untuk memberikan pemahaman yang menyeluruh terkait kedudukan yang benar tentang perbedaan seks dalam Perjanjian Baru pada seseorang. (Guthrie 2008: hlm 155).

Di dalam kitab-kitab Injil Sinoptik mengenai pelayanan Yesus, terdapat banyak keterangan yang memperlihatkan apa yang dimaksud memanusiakan sikap pria terhadap wanita. Tuhan Yesus dan para penulis kitab-kitab Injil mengakui kesamaan wanita dan pria. Maka kisah kelahiran Yesus terpusat kepada seorang anak dara, hal ini menempatkan seorang perempuan yang bernama Maria pada kedudukan yang paling terhormat. Dia dipakai oleh Allah sebagai alat-Nya. Tentu Allah dapat menggunakan cara yang lain, namun Yesus masuk ke dalam dunia sebagai manusia, sama seperti manusia lain melalui rahim seorang perempuan; ini adalah bukti yang tidak terbantahkan bahwa Ia betul-betul seorang manusia (Guthrie 2008: 155).

Kisah kelahiran yang diceritakan Lukas didominasi oleh dua orang perempuan yaitu Maria dan Elisabet. Semua catatan Kitab-kitab Injil sinoptik mengenai masa kesengsaraan dan kebangkitan Yesus menekankan pentingnya peran seorang perempuan. Bahkan Lukas 
seolah-olah ingin menyoroti secara khusus kedudukan perempuan dalam misi Yesus sebagai Mesias. Catatan Mat. 4:23-25, 9:35-38, 14:13-21 dan Mark. 1:32-34 mengatakan bahwa Tuhan menolong manusia pada umumnya, Dia tidak membeda-bedakan antara pria maupun wanita. Maka banyak kisah yang dicatat tentang pelayanan Yesus kepada kaum perempuan, seperti Ia menyembuhkan mertua Petrus, anak perempuan rumah ibadat Yahudi, dan perempuan yang menderita pendarahan, anak gadis dari Kanaan. Pokok penting dalam peristiwa itu ialah ucapan Yesus bahwa imannya telah menyelamatkan. Orangtua haruslah dihormati sebagaimana perintah Tuhan (Mat.15:4). Yesus menghargai pentingnya kedudukan perempuan dalam keluarga, Ia memberikan perhatian khusus kepada Ibu-Nya.(Guthrie 2008: hlm 155-156)

\section{KAJIAN LITERATUR}

\section{Perempuan dalam Perjanjian Lama}

Kitab Kejadian dalam Perjanjian Lama mencatat tentang kedudukan, peran dan karakteristik seorang perempuan dijelaskan dalam (Kej. 1:27,28) yang mengatakan "Maka Allah menciptakan manusia itu menurut gambar-Nya, menurut gambar Allah diciptakannya dia; laki-laki dan perempuan diciptakan-Nya mereka”.(Selvaraj 2001: 1112)

Perempuan dalam Bahasa Ibrani isysya dan Bahasa Yunani gune. Perempuan dan lakilaki diciptakan sesuai gambar Allah (Kej. 1: 27), dan perempuan merupakan 'penolong sepadan' untuk pria (Kej. 2:20). Di dalam hukum Ibrani ibu harus dihormati (Kel 20:12), disegani (Im. 19: 3) dan ditaati (Ul. 12:18). Perempuan sangat krusial perannya dalam keluarga seperti memberikan nama untuk anak, mendidik dan membina anak pada usia dini. Seorang nazir yang mengkhususkan dirinya bagi Tuhan akan mengucapkan nazarnya (Bil. 6:2). Pada hari Sabat wanita juga dibebaskan dari pekerjaan (Kel. 20:10), dan apabila dijual sebagai budak, haruslah dibebaskan sama seperti laki-laki pada tahun yang ketujuh. Perempuan yang tidak mempunyai ahli waris laki-laki, maka dirinya itu dapat memiliki tanah secara penuh pada dirinya sendiri. Seorang pria harus menikah dengan wanita sesukunya, supaya wanita asing tidak mempengaruhinya untuk tidak beribadat kepada Tuhan.(Ensiklopedia Alkitab Masa Kini 2002: 240)

Suroso dalam Wijaya menuliskan: Wanita Yahudi begitu dihargai dalam sebuah pernikahan. Ajaran Hukum Taurat menekankan bahwa laki-laki wajib untuk menciptakan relasi yang baik dengan perempuan. Perempuan mempunyai hak untuk membeli, menjual, dan memiliki tanah, serta menyusun kontrak mereka sendiri. Ketidaksamaan kewajiban serta tanggung jawab diantara keduanya pun diakui, dan dalam beberapa hal tanggung jawab perempuan dianggap lebih penting. Kaum wanita menduduki posisi terhormat dalam Yudaisme sejak jaman Perjanjian Lama (Wijaya 2018: 142).

Maka dari bagian ini dijelaskan bahwa rencana Tuhan nyata bagi laki-laki dan perempuan; Allah menjadikan mereka penguasa atas makhluk ciptaan-Nya. Hal ini berarti laki-laki dan perempuan mempunyai kedudukan dan otoritas yang sama. Kesetaraan lakilaki dan perempuan dijelaskan dalam 1 Petrus. 3:7 "Demikian juga kamu, hai suami-suami, hiduplah bijaksana dengan isterimu, sebagai kaum yang lebih lemah! Hormatilah mereka sebagai teman pewaris dari kasih karunia".(Selvaraj 2001: hlm 11 )

Allah menciptakan perempuan, supaya ia menjadi penolong dan pendamping laki-laki (Kej. 2:18). Tuhan tidak menjadikan perempuan budak atau pembantu laki-laki. Kesetaraan mulai tercemar ketika Hawa, (perempuan yang pertama dan Adam, laki-laki pertama berbuat dosa terhadap Tuhan). Tuhan mengutuk mereka, perempuan akan bersusah payah, waktu mengandung akan Kubuat sangat banyak; dengan kesakitan engkau akan melahirkan anakmu; namun engkau akan berahi kepada suamimu dan ia akan berkuasa atasmu" (Kej. 3:16). Maka ditemukan juga di dalam Perjanjian Baru "Hai isteri, 
tunduklah kepada suamimu seperti kepada Tuhan" (Ef. 5:22). Ketidaktaatan ini menyebabkan terjadinya ketidakseimbangan pada kesatuan dan kesetaraan yang tadinya sempurna antara laki-laki dan perempuan. Akibatnya, perempuan sepertinya telah dibuat lebih rendah derajatnya daripada laki-laki. Tetapi walaupun perempuan diminta tunduk kepada otoritas laki-laki, tetapi di mata Tuhan ia tidak lebih rendah derajatnya dari pada laki-laki. Apakah perempuan akan tetap menjadi hamba bagi laki-laki. Dalam Perjanjian Baru dijelaskan bagaimana nanti Yesus menghapus segala kuk perhambaan dosa ketika Dia mati disalib dan bangkit dari kematian-Nya.(Selvaraj 2001). Maka segala ketidaksetaraan dipulihkan menjadi seperti semula sehingga kedudukan dan peran laki-laki maupun perempuan menjadi sama.

\section{Perempuan dalam Perjanjian Baru}

Pendapat yang keliru tentang perempuan yang mana kondisi wanita Yahudi di Palestina pada jaman Yesus yang tidak dianggap, sebagai akibat dari tradisi Talmud. Pada masa awal Yudaisme, perempuan boleh membacakan Taurat dan bernubuat, namun pada masa Yesus, muncul larangan untuk mereka membacakan Taurat di Sinagoga disebabkan mengalami "kenajisan" secara berkala. Pertanyaan terkait apakah perempuan boleh mempelajari Taurat juga merupakan topik perdebatan yang sengit. Berdasarkan aturan, yang memperoleh pendidikan semacam itu hanyalah istri para rabi saja. Menurut Taurat Yahudi, dalam Yudaisme abad pertama, perempuan tidak dapat menjadi saksi, dan dalam bidang keagamaan atau kepemimpinan juga tidak mendapatkan peran penting. Perempuan telah dijadikan sebagai kaum yanag tidak diperhitungkan dan tidak berdaya di negeri yang dipimpin oleh kaum elit religius (Wijaya 2018: hlm. 143)

Menanggapi pemahaman yang keliru tersebut di atas, Suroso dalam Wijaya mengatakan bahwa Tuhan Yesus datang menawarkan pendekatan yang revolusioner. Dia dengan gamblang menyambut para perempuan dan menjadikannya rekan seperjalanan dalam pelayanan-Nya (Lukas 8:1-3). Yesus juga memotivasi Maria dan Marta untuk duduk di dekat kaki-Nya, mendengarkan pengajaran dan menjadi murid-murid-Nya (Lukas 10:3842). Cara Tuhan Yesus menghargai perempuan merupakan hal baru yang jauh berbeda dengan cara orang-orang Farisi dan Saduki memberikan perlakuan. Karya penebusan Kristus telah menghancurkan semua dinding pemisah; setiap orang percaya, setiap suku bangsa, memiliki akses yang sama dihadapan-Nya dan menghadirkan era baru dalam konteks hubungan antar manusia-lintas ras, gender maupun status sosial.(Wijaya 2018:hlm. 143)

Kitab Lukas menyebutkan Maria ibu Yesus sebagai yang 'diberkatilah engkau diantara perempuan' (Luk. 1:42). Banyak hal yang tidak dia mengerti tentang Anak-Nya, dia memendam dan merenungkan segala perkara itu di dalam hatinya (Luk. 2:19). Kisah perjumpaan Yesus dengan para perempuan yang melayani-Nya banyak diceritakan dalam kitab-kitab Injil. Didalamnya diceritakan bagaimana kaum perempuan tersebut mempersiapkan keperluan perjalanan, memberikan tumpangan, memperlihatkan kasih, memperhatikan kuburan-Nya termasuk melaksanakan upacara terakhir dengan Yesus dan menjadi saksi mata ketika kebangkitan-Nya.

\section{Perempuan dalam Ajaran Yesus}

Pada umumnya cara Yesus Kristus mengajar adalah dengan tidak mengeluarkan katakata yang menghina atau merendahkan martabat kaum wanita. Kaum Hawa tidak pernah dijadikan bahan tertawaan ataupun kritikan bahkan tidak pernah dianggap rendah. Peringatan keras Yesus terhadap perselingkuhan dan perceraian dalam Mat.5:27-28 dan 19:3-10, bahwa kaum Hawa tidak boleh diperlakukan sebagai objek seks oleh para lelaki. 
Yesus menganggap perceraian suami-isteri sebagai ketegaran hati manusia.(Siahaya 2018: hlm 32)

Yesus di dalam khotbah-Nya memakai dua orang tokoh perempuan sebagai analogi untuk menyindir ketidaksetiaan orang Israel. Yesus mengajarkan keteladanan seorang perempuan janda Sarfat yang murah hati untuk menegur kaum lelaki di kota Nazaret karena kepelitannya (Luk. 4:25-26). Contoh kedua ialah ratu Sheba yang datang dari daerah selatan untuk mendengarkan hikmat Raja Salomo. Ratu Sheba yang bijaksana berbeda jauh dengan para ulama Yahudi dari golongan Farisi yang walaupun mempelajari Taurat tetapi tidak memahami dan tidak mempercayai Hikmat Ilahi (Luk. 11:31).(Siahaya 2018: hlm 33-41).

Yesus memandang bahwa perempuan dan laki-laki memiliki derajat yang sama dan tidak ada yang lebih rendah dari yang lainnya. Kaum perempuan sangat dihormati oleh Yesus hal ini seharusnya menjadi pelajaran bagi orang percaya untuk tidak merendahkan nya.

Yesus menyadari bahwa kedatangan-Nya mengakibatkan ketegangan di dalam keluarga, yang akan mempengaruhi anak perempuan maupun anak laki-laki (Mat. 10:35). Kedua orangtua haruslah dihormati sesuai Firman Tuhan (Mat. 15:4 band. Kel.20:12). Tuhan menghargai pentingnya kedudukan dan peran seorang perempuan dalam keluarga, sehingga ia memberikan perhatian khusus kepada Ibu-Nya (Yoh. 19:27) dan Dia juga besar bersama saudara-saudara-Nya perempuan dan juga saudara-Nya laki-laki (Mat. 13:56). Saat Yesus menjelaskan siapa yang menjadi sanak saudara kepada murid-murid-Nya, Ia menyebutkan saudara laki-laki, saudara perempuan dan ibu-Nya (Guthrie 2008, 157). Hal ini menjelaskan betapa pentingnya kedudukan seorang perempuan dan kesetaraannya dengan laki-laki. Ketika Yesus dibawa ke Golgota usai persidangan dikatakan, sejumlah wanita menangisi serta meratapi-Nya. Selain itu para wanita tersebut juga berjaga-jaga di depan kayu salib (Luk. 23:49), dan makam tempat Yusuf dari Arimatea membaringkan mayat Yesus (Luk. 23:56). Mereka juga memberikan rempah-rempah serta meminyaki mayat Yesus serta menjadi saksi utama ketika kebangkitan Yesus diberitakan (Luk. 24:1).(Guthrie 2008: hlm 157)

Berdasarkan pandangan di atas maka dapat disimpulkan bahwa Yesus memandang perempuan memiliki kedudukan yang sama dan setara dengan laki-laki. Hal ini juga ingin memberikan pengajaran kepada setiap orang bahwa perempuan juga menjadi revolusioner. $\mathrm{Hal}$ ini seharusnya mengubah pola pikir setiap orang yang memandang rendah perempuan dengan tujuan supaya mereka juga dihormati, dihargai dan ditempatkan kepada kedudukan yang sama dengan laki-laki.

\section{Perempuan dalam Pandangan Rasul Paulus}

Pada dasarnya perempuan di dalam budaya Yahudi dan non-Yahudi dianggap lebih rendah dan tidak mempunyai hak yang bebas. Bagaimana pandangan Rasul Paulus tentang kedudukan seorang perempuan dalam lingkungan jemaat. Rasul Paulus menentang polapola zaman itu yang membedakan kedudukan laki-laki dan perempuan, Paulus secara tegas mengatakan dalam Galatia 3: 28 yang menegaskan di dalam Kristus "tidak ada laki-laki atau perempuan". Rasul Paulus menghubungkan hal ini dengan penghapusan perbedaan antara budak dan orang yang bebas. Hal ini karena Rasul Paulus melihat ada perbedaan orang yang tinggal di dalam Kristus dan yang tidak tinggal di dalam Dia. Ia ingin menunjukkan bahwa keidealan itu terdapat di dalam Dia, perbedaan akan tetap ada. Di dalam surat-surat Rasul Paulus tidak disebutkan di hadapan Allah ada perbedaan kedudukan perempuan dan laki-laki. Baik perempuan maupun laki-laki memerlukan keselamatan dengan cara yang sama dan atas dasar yang sama yaitu di dalam Yesus Kristus. Di dalam Teks 1 Tim. 5:2-3 Paulus menasehati Timotius untuk memperlakukan 
perempuan-perempuan tua sebagai ibu dan perempuan-perempuan muda sebagai adik. Janda yang benar-benar janda diberikan penghormatan khusus. Di bagian ini tidak ada hal untuk menguasai perempuan. Hal ini seharusnya menjadi pelajaran untuk pendekatan tentang kedudukan seorang perempuan di dalam lingkungan jemaat.(Guthrie 2008: hlm 185-186)

Di dalam (Gal. 3:28) dan melalui nats 1 Tim. 2:11-15 memberikan penjelasan terkait dengan peran dan sejauh mana kaum Hawa dilibatkan dalam ibadah jemaat. Dalam Galatia 3:28 menyatakan bahwa dalam hal keselamatan kedudukan wanita tidak berbeda dengan pria. Keduanya sama-sama diangap sebagai anak-anak Allah dan ahli waris janji-janji Allah ketika percaya kepada Tuhan. 1 Timotius 2:11-15 Rasul Paulus melihat adanya tindakan yang menyimpang dari ajaran Alkitab sehingga ia perlu menegaskan dalam bagian ini bagaimana peran dan kedudukan seorang perempuan. Hal ini terkait dengan munculnya masalah dalam jemaat yang disebabkan oleh perempuan-perempuan yang mendominasi dalam ibadah gereja. Perempuan sudah mengambil peran dan kedudukan seorang laki-laki sehingga Paulus perlu menasehatkan mereka.(Wauran et al. 2015: hlm 11-12). Hal ini bukan berarti perempuan tidak boleh mengambil perannya, tetapi ada halhal yang telah ditetapkan Firman Tuhan untuk tidak dilanggar.

Galatia 3:28 menjelaskan bahwa ketika seseorang datang kepada Tuhan maka semua perbedaan rohani itu telah dihapuskan. Bagian ini membicarakan tentang kedudukan sedangkan 1 Timotius 2 menekankan posisi dan otoritas yang mana perempuan itu sebenarnya di bawah kekuasaan laki-laki. Hal inilah yang menjadi alasan seorang wanita tidak bisa memimpin laki-laki. Kaum Hawa boleh terlibat dalam ibadah maupun mengajar namun tetap berada di bawah otoritas atau kepemimpinan kaum Adam. Bagian ini menggambarkan suatu hubungan yaitu antara Kristus dengan jemaat maupun konteks hubungan suami dan isteri 1 Kor. 11:3 "Tetapi aku mau, supaya kamu mengetahui hal ini, yaitu kepala dari tiap-tiap laki-laki ialah Kristus, kepala dari perempuan ialah laki-laki dan kepala dari Kristus ialah Allah. Maka meskipun ini mengacu pada kasus yang muncul dalam jemaat namun sebenarnya Paulus hendak menegaskan ulang dasar dari suatu hubungan serta bagaimana itu diaplikasikan dalam ibadah jemaat.(Wauran et al. 2015:1215)

Di dalam surat-suratnya Paulus menyebutkan perempuan sebagai rekan-rekan sekerja Paulus, tetapi perempuan-perempuan ini bukanlah penolong ataupun asisten Paulus. Namun, acuan-acuan Paulus kepada misionaris perempuan tidak mencerminkan status seksual dan peranan-peranan jenis kelamin mereka, ataupun menggolongkan mereka sebagai janda ataupun perawan. Paulus mengukuhkan bahwa perempuan bekerja bersamanya dalam tingkat yang sama. Perempuan-perempuan kaya pada abad pertama terkenal karena membuat tempat tinggal dan rumah-rumah mereka bagi ibadah-ibadah Timur dan perayaan-perayaan ibadahnya yang ekstatis. Gereja rumah adalah faktor penentu dalam gerakan misi sejauh mereka memberikan ruang, dukungan dan kepemimpinan yang sesungguhnya bagi komunitas. Jemaat-Jemaat rumah adalah tempat bagi orang-orang Kristen mula-mula untuk merayakan perjamuan Tuhan dan memberitakan kabar baik.(Wassar 2021: hlm 19)

Kesetaraan bukan berarti menghilangkan otoritas laki-laki sebagai yang utama di dalam keluarga Kristen. Perempuan adalah kesetaraan yang harus saling melengkapi laki-laki dengan tunduk kepada otoritas dan hal-hal prinsip terhadap laki-laki. Kristus ingin menghubungkan kesetaraan ini supaya baik laki-laki maupun perempuan mengambil peran dan kedudukannya masing-masing. 


\section{Perlakuan Budaya Yunani Terhadap Perempuan}

Witherington III menjelaskan bahwa dalam masyarakat Yunani, selain kaum perempuan yang menjadi pelacur dan budak, kaum perempuan terbagi tiga kategori yakni "anthenias citizen, concubines, and companions or foreign woman" (Chandra Gunawan 2014: hlm 15). Pada umumnya kaum perempuan Yunani dianggap lebih rendah statusnya dari kaum pria, namun tidak semua kaum perempuan mengalami perendahan status; ada kaum perempuan tertentu yang mempunyai status sosial tinggi dan dihormati dalam masyarakat. Evans dalam Gunawan juga menjelaskan pembatasan-pembatasan yang diberikan kepada kaum perempuan Yunani dan itu dapat terlihat dalam perlakukan mereka dimana mereka terkadang tidak boleh ke pasar, tidak boleh bertemu sanak familinya dan cenderung terisolir dalam rumahnya (Gunawan 2014:15 b). Bahkan untuk seorang perempuan yang menjadi warga Athena sekalipun, mereka dibatasi haknya dengan tidak boleh menjadi saksi di pengadilan, kecuali untuk kasus bunuh diri. Dalam hal keagamaan, sulit untuk melihat sikap masyarakat Yunani terhadap kaum perempuan, memang bila melihat bahwa dalam ritual keagamaan mereka ditemukan indikasi adanya keterlibatan kaum perempuan, namun peran mereka adalah sebagai pelacur (Gunawan 2014: hlm 15).

Dari penjelasan diatas, budaya juga mempengaruhi harkat dan martabat seorang perempuan. Perempuan dalam kebudayaan Yunani dianggap kaum yang lemah, tidak mengambil andil di dalam kehidupan sosial, bahkan hak-hak mereka diambil dan dijadikan sebagai hiburan.

\section{Perlakuan Budaya Romawi Terhadap Perempuan}

Masyarakat Romawi memiliki pandangan yang lebih baik terhadap kaum perempuan dibandingkan orang-orang Yahudi maupun Yunani, sebab mereka memandang kaum perempuan setara dengan kaum laki-laki. Dalam budaya Romawi, kaum perempuan memiliki hak-hak dalam ekonomi, politik, keagamaan dan dalam perceraian. Dalam hal keagamaan kaum perempuan Romawi dipandang sederajat dengan kaum laki-laki, hal ini nampak dalam salah satu ukiran batu di Museo yang memperlihatkan adanya kaum perempuan dengan tudung dikepalanya sedang membawa persembahan.(Gunawan 2014: hlm 16)

Kaum perempuan lebih dihargai dan dihormati bagi budaya Romawi. Perempuan memiliki kesetaraan dengan laki-laki, bahkan kaum perempuan dijamin kehidupan mereka secara sosial, ekonomi, politik, keagamaan dan sampai urusan perceraian.

\section{Perlakuan Budaya Yahudi Terhadap Perempuan}

Dalam masyarakat Yahudi, kaum perempuan seperti halnya dalam masyarakat Yunani dipandang kurang dihargai dari kaum laki-laki. Yosefus mengatakan bahwa kaum wanita dalam segala hal lebih inferior dibandingkan laki-laki. Warisan tradisi yang diterima oleh orang-orang Yahudi bahwa seseorang harus berbahagia karena tidak dilahirkan sebagai perempuan memperlihatkan cara pandang yang negtif terhadap kaum perempuan. Dalam hal ibadah, kaum perempuan juga menempati posisi kedua; hal ini nampak misalnya saja dalam hal pemberian Taurat yang hanya diberikan kepada kaum laki-laki, perempuan tidak dijinkan untuk menjadi saksi, dan tempat kaum perempuan dipisahkan dari kaum laki-laki.(Gunawan 2014: hlm 16-17)

Meskipun secara umum, pandangan orang Yahudi terhahap perempuan adalah negatif, namun ada juga yang memandang sebaliknya; ada yang menemukan perspektif yang berbeda dari cara pandang umum masyarakat Yahudi, tokoh yang kemudian diperlihatkan sebagai pahlawan justru adalah kaum perempuan. Isu mengenai kaum laki-laki yang diperlakukan lebih tinggi dari kaum perempuan memang tidak menjadi isu sepenting masalah ketegangan hubungan orang Yahudi dan non-Yahudi; meskipun demikian, isu ini 
turut, khususnya mengenai keterlibatan kaum perempuan dalam pertemuan ibadah, menjadi persoalan dalam komunitas gereja mula-mula. Dalam 1 Korintus 11:2-16; 14:3440 menemukan adanya indikasi persoalan dalam jemaat yang muncul karena isu keterlibatan kaum perempuan dalam ibadah; isu ini jelas merupakan bagian dari isu sosial dari masyarakat Yahudi, Yunani-Romawi pada abad pertama Masehi.(Gunawan 2014: hlm 17-18)

\section{METODE PENELITIAN}

Metode penelitian dalam artikel menggunakan metode penelitian kualitatif. Metode penelitian ialah suatu aktivitas ilmiah yang dilakukan secara bertahap yang diawali dengan penentuan topik, pengumpulan informasi serta menganalisis informasi tersebut sehingga mendapatkan suatu pemahaman atas topik, gejala ataupun isu-isu tertentu.(Raco 2010, 2) Sedangkan penelitian kualitatif merupakan suatu aktivitas ilmiah yang terencana, terstruktur, tersistematis serta mempunyai tujuan tertentu baik secara praktis maupun teoritis.(Raco 2010). Karena itu jelas bahwa penelitian kualitatif berfokus pada makna dalam konteks serta pengumpulan informasi, dengan kepekaan terhadap makna yang mendasarinya saat mengumpulkan serta menafsirkan informasi tersebut.(Merriam 2009, 2). Metode ini untuk mengkaji literatur-literatur yang dikumpulkan baik berbentuk buku ataupun artikel yang sesuai dengan topik ini. Sedangkan pokok-pokok pikiran yang diuraikan dalam tulisan ini menggunakan analisis deskriptif.

\section{HASIL DAN PEMBAHASAN}

\section{Sikap Gereja Terhadap Perempuan dalam Perspektif Perjanjian Baru}

Sikap Yesus terhadap kaum perempuan berbeda dari sikap masyarakat Yahudi pada umumnya. Sikap yang berbeda dari Yesus terhadap kaum perempuan terlihat dalam Lukas 8:1-3. Yesus adalah Perjanjian Baru yang memperjuangkan kesamaan dan kesederajatan di antara pria dan wanita. Yesus, dalam perjalanan pelayanan-Nya, tidak jarang memberikan perhatian kepada kaum perempuan. Yesus juga bersahabat dengan mereka (lihat. Luk 7:3550). Karena itu, dalam pelayanan karya misioner-Nya Yesus "mengijinkan" kaum perempuan turut serta. Dan harus diakui bahwa kaum perempuanlah yang senatiasa setia mengikuti Yesus. Jika dibandingkan keduabelas rasul mengejar-ngejar kesuksesan dan kedudukan terhormat, kaum perempuan tidak demikian (lihat. Luk 7:37- 38). Jika kedua belas rasul kecewa dan meninggalkan Yesus ketika Ia ditangkap dan disalibkan, kaum perempuan justru terus "mengikuti" 'jalan salib sampai wafat-Nya (Kitab Injil mencatat: Maria Magdalena, Yoana, Susana, Maria, Salome, dan banyak perempuan lain mengikuti Yesus dari Galilea sampai di bawah salib, Mrk 15:40-41, Mat 27:55-56, Luk 8:1-3;23:55; Yoh 19:25). (Jemali 2018: hlm 207)

Sikap Yesus dalam Yohanes 8: 11, seharusnya menjadi pelajaran penting bagi gereja Tuhan masa kini, bahwa tidak cepat menghakimi. Gereja harus membawa orang berdosa pada pertobatan. Menurut Marshall, sikap Yesus dalam menempatkan kaum perempuan dalam kumpulan murid-murid-Nya tidaklah dianggap biasa oleh orang-orang zamannya; jika dibandingkan dengan penjelasan yang diberikan oleh Kroeger bahwa kaum perempuan di Palestina pada umumnya hanya hidup dalam lingkup tempat tinggalnya (rumah), maka tindakan Yesus untuk menyertakan kaum perempuan dalam perjalanan misinya bukanlah hal yang dianggap lazim oleh masyarakat Yahudi abad pertama Masehi. (Gunawan 2014: hlm 20). Pada masa itu perempuan masih berteriak untuk bebas dari jajahan tata norma hidup orang Yahudi dan Yunani yang kerap kali menganggap kaum perempuan lebih rendah dan hak mereka diambil begitu saja. 
Menurut Marshall, tujuan dari dituliskannya bagian ini oleh Lukas adalah untuk memperlihatkan kualifikasi dari dapat dipercayanya kesaksian kaum wanita yang menjadi saksi kebangkitan Yesus sebab mereka adalah orang-orang yang pertama sekali menyaksikan pelayanan Yesus, selain itu bagian ini juga dituliskan serta untuk memberikan dorongan kepada kaum perempuan dalam gereja mula-mula untuk terlibat aktif dalam pelayanan di gereja. Apa yang Lukas tulis tentunya bertentangan dengan budaya Yahudi dan Yunani sebab dalam kehidupan orang Yahudi, kesaksian kaum perempuan tidak dapat diterima dan dalam kebudayaan Yahudi serta Yunani, kaum perempuan tidaklah memiliki kebebasan dalam pelayanan keagamaan; itulah sebabnya jika Lukas kemudian menuliskan kisah mengenai kaum perempuan yang melibatkan dalam pelayanan sekaligus diberikan tugas untuk menjadi saksi kebangkitan Kristus seperti halnya kaum laki-laki, maka hal ini jelas menunjukkan sikap yang berbeda dari Lukas, seperti halnya Yesus, dari komunitas zamannya yang cenderung merendahkan kaum perempuan, dalam memandang status serta kedudukan kaum perempuan dalam pekerjaan Tuhan.(Gunawan 2014: hlm 20-211)

Di dalam Perjanjian Baru secara khusus jika dilihat dari budaya Yahudi dan Yunani dari penjelasan di atas mereka tidak secara terang-terangan menolak kehadiran perempuan di dalam komunitas sosial seperti memimpin dalam rumah ibadat, kegiatan sosial dan lainnya.

Sikap Paulus terhadap kaum perempuan pada dasarnya bersifat positif, hanya saja dalam tulisannya sikap Paulus terlihat seolah-olah tidak konsisten. Dalam 1 Kor. 11:2-16 Paulus mengijinkan perempuan untuk terlibat aktif dalam pelayanan baik untuk berdoa bahkan untuk menyampaikan nubuat; namun dalam 1 Kor. 14: 34-40 seperti halnya dalam 1 Tim. 2:12 Paulus menolak perempuan untuk berbicara dalam pertemuan ibadah. Untuk memahami sikap Paulus terhadap perempuan, harus memulainya dari Gal. 3:28 dimana Paulus mencocokan antara hubungan Yahudi dan non-Yahudi dalam Tuhan dengan relasi antara pria dan wanita; sebagaimana dalam konteks hubungan Yahudi dan bukan Yahudi bahwa mereka adalah sederajat, demikianlah kedudukan pria dan wanita di dalam Tuhan. Walaupun dilihat dari konteks sosial zamannya, kaum perempuan tidaklah dinilai dan diperlakukan sama seperti halnya kaum laki-laki, namun Paulus jelas menolak hal tersebut. Meskipun demikian, orang percaya masih berhadapan dengan pertanyaan "Mengapa Paulus kemudian melarang perempuan untuk berbicara dalam pertemuan ibadah?" Paulus sebenarnya tidak melarang kaum perempuan untuk berbicara dalam pertemuan ibadah; dalam 1 Korintus 11 dapat dilihat bahwa Paulus seperti halnya dalam Perjanjian Lama dapat menerima bahwa kaum perempuan dapat mnerima panggilan dan karunia dari Tuhan untuk menjadi penyampai pesan Allah (bernubuat/berkhotbah). Itulah sebabnya kalaupun Paulus melarang perempuan berbicara dalam 1 Kor. 14:34-40, hal tersebut pasti bukan disebabkan karena sifat orang tersebut sebagai seorang perempuan; Paulus melarang perempuan dalam konteks 1 Kor. 14:34-40 mungkin karena apa yang dia lakukan mengganggu ketertiban dari ibadah atau mungkin karena perempuan tersebut melakukan apa yang bukan menjadi kewenangan atau panggilan atau karunianya yakni mengevaluasi nubuat yang disampaikan oleh salah satu jemaat ;hal yang sama kemungkinan menjadi latar belakang nasehat Paulus dalam 1 Tim 2:22 bagi kaum perempuan. (Gunawan 2014: hlm 22)

Mengacu pada pemaparan di atas, maka perempuan jika dipandang dari sikap gereja mula-mula, mereka adalah kaum yang juga mempunyai tugas dan kedudukan penting di dalam gereja dengan porsi masing-masing dan dengan catatan tidak mengambil porsi orang lain di dalam gereja. Jelas bahwa setiap karunia harus sejalan dengan perannya, bukan menyimpang dari peran dan kedudukannya. 


\section{Kewajiban Seorang Perempuan}

- Tunduk kepada Suami

Di dalam Perjanjian Lama perempuan telah "dihukum" oleh Allah karena pelanggaran yang telah dilakukan. Allah berkata kepada Hawa, "engkau akan birahi pada suamimu dan ia akan berkuasa atasmu" (Kej 3:16). Akibatnya seroang perempuan haruslah tunduk kepada suaminya. Hukuman ini terus berlaku sampai kepada Perjanjian Baru, ketika Paulus memberitahukan pada isteri orang Kristen, "tunduklah pada suamimu sendiri, seperti kepada Tuhan" (Ef 5:22). Inti dari semuanya merendahkan diri seorang akan yang lain di dalam takut akan Tuhan.(Henk Ten Nape 2006: hlm 15)

Walaupun seorang wanita harus tunduk kepada suaminya, tidak berarti ia lebih rendah dari suaminya. Arti penundukan adalah bahwa isteri rela dipimpin oleh suaminya. Rasul Paulus mengajarkan bahwa penundukan diri berlaku terhadap ke dua belah pihak (baik suami maupun isteri) "dan rendahkanlah dirimu seorang kepada yang lain di dalam takut akan Yesus Kristus" (Ef 5:21). Di Galatia 3:28, Paulus mengatakan bahwa di dalam Kristus, status antara pria dan Wanita sama dan tidak adanya perbedaan. (Henk Ten Nape 2006: hlm 15)

Artinya kita harus mengerti bahwa peranan yang digariskan Alkitab bagi seorang wanita itu sangat indah dan mulia. Bahkan hingga masa Perjanjian Baru para wanita tetap dipakai oleh Tuhan. Yesus dilahirkan dari rahim Maria seorang perempuan. Dialah Tuhan dan Juruselamat dan saat kebangkitan-Nya yang pertama menyaksikannya adalah perempuan. Selain itu, perempuan merupakan penolong laki-laki sebagaimana Allah katakan pada Adam bahwa tidak baik baginya untuk hidup seorang diri saja. Nyatalah di sini bahwa Allah merancangkan manusia untuk tidak hidup sendiri. Sejak semula, Allah menjadikan wanita sebagai penolong bagi laki-laki (Lumban Gaol 2014: 28). Tujuannya agar masing-masing dapat saling berbagi, saling bekerja sama dan hidup berdampingan sebagai satu kesatuan di dalam Tuhan. Lumban Gaol menambahkan bahwa itulah kesejawatan, yang menunjukkan kerjasama, bekerja secara berdampingan, melayani bersama, memenangkan jiwa bersama."Biarlah para pria Kristen belajar bahwa isteri-isteri mereka adalah "penolong" dalam kehidupan ini dan pasangan sejawat mereka (Kej.2:21)"'(Lumban Gaol 2014: hlm 29)

Pada saat Tuhan Allah membuat manusia tidur nyenyak, Dia mengambil salah satu rusuk daripadanya dan dari rusuk tersebut dijadikanlah seorang perempuan. Maka bersatulah manusia itu: Inilah dia tulang dari tulangku dan daging dari dagingku" (Kej 2:21-23). Demikianlah seharusnya yang dirasakan seorang pria terhadap istrinya untuk mengasihinya sebagai dagingnya sendiri (Ef 5:28,29)."Ia dinamai perempuan, sebab ia diambil dari laki-laki". Inilah makna penciptaan sejarah perjanjian yang berpusat dan bertujuan pada Yesus Kristus (Lumban Gaol 2014:29)

Perempuan menjadi sarana tujuan penciptaan, dimana Allah memakai perempuan untuk melumpuhkan Iblis. Melalui anak dara telah lahir Juruselamat ke dalam dunia, kuasa Iblis dipatahkan dan tujuan Allah tergenapi.

\section{Hak-Hak Seorang Perempuan}

Kedudukan hukum bagi kaum perempuan di Israel lebih lemah daripada pria. Seorang suami dapat menceraikan isterinya jika didapati isterinya sedang berzinah. Tepat berbeda dengan isteri tidak dapat diperbolehkan menceraikan suaminya karena alasan apapun (Ul 24:1-4). Di dalam kisah seorang perempuan yang kedapatan berzina oleh orang Farisi, mereka membawanya kepada Yesus untuk dihukum, tetapi karena Yesus tahu bahwa hati mereka tidak adil Yesus memberikan pernyataan kepada mereka siapa yang tidak berdosa maka lemparilah perempuan ini dengan batu, dengan perlahan-lahan satu persatu orang Farisi meninggalkan Yesus. Mengapa demikian? Karena mereka hanya menuntut sang 
perempuan sedangkan yang laki-laki dibiarkan lolos tanpa harus dihukum. Karena memang hak dan kedudukan perempuan tidak dianggap begitu penting di kalangan orang Yahudi pada waktu itu. Oleh karena itu Yesus datang sebagai pembela hak-hak orang lemah seperti kaum perempuan (Yoh 8:3-11). (4.30, n.d.)

\section{a) Hak bebas dari sikap diskriminatif laki-laki}

Di alam Perjanjian Lama perempuan sama sekali tidak mendapat hak yang istimewa. Sering kali perempuan hanya tempat persinggahan laki-laki dan menjadi budak. Hak-hak mereka dirampas dan mereka tidak dilibatkan di dalam kegiatan sosial terutama bagi kebudayaan Yahudi dan Yunani. "Diskriminasi dan ketidakadilan" dialami oleh para perempuan Yahudi seperti yang terjadi pada para perempuan di zaman kuno, maka kehadiran Yesus sangat berdampak pada terciptanya kehidupan yang sederajat. Yesus sering mengkritik ahli-ahli Taurat, orang-orang Farisi, maupun masyarakat pada saat itu mengenai posisi laki-laki dan perempuan, mengenai masalah suci dan najis, mengenai hari Sabat, dan sebagainya. Tindakan dan pengajaran Yesus menjadi dorongan bagi keterlibatan perempuan dalam pelayanan-Nya, karena Yesus telah memperjuangkan nilai-nilai kesetaraan perempuan. Pada akhirnya semakin banyak perempuan yang ingin terlibat dalam pelayanan Yesus. (Siagian 2019: hlm 37-83)

Perjumpaan Yesus dengan kelompok orang yang dikucilkan, termasuk para perempuan telah membawa perubahan yang besar. Kehadiran Yesus dianggap sebagai pelopor perubahan dan memberi pembebasan bagi kaum perempuan. Kaum perempuan kini telah terlepas dari berbagai penindasan, tindakan diskriminatif, bahkan belenggu yang cukup lama mengikat mereka. Setiap tindakan yang telah Yesus lakukan terhadap perempuan telah memberi makna pembebasan dari tindakan diskriminatif yang dialami oleh kaum perempuan. (Siagian, n.d.)

Maka dari penjelasan di atas Yesus adalah motor utama yang membebaskan wanita dari sikap diskriminatif dan membela mereka dengan tujuan memberitahukan segala tindakan bahwa perempuan dan laki-laki mempunyai kesetaraan dalam hak bergaul, berpendapat, dan lain-lain. Dalam Perjanjian Baru Yesus membawa perubahan yang besar bagi kaum perempuan. Yesus bahkan tidak membeda-bedakan laki-laki dan perempuan. Perempuan dan laki-laki mempunyai hak-hak yang sama di hadapan Allah maupun manusia. Yesus sendiri banyak bertemu dengan kaum perempuan di dalam pelayanan-Nya. Seperti seorang Janda di Sarfat, perempuan Samaria, perempuan yang berzina dan banyak lagi. Semuanya diubahkan oleh Yesus melalui perhatian dan pelayanan-Nya. Jelas ajaran Yesus ingin menghilangkan sikap diskriminatif dari kalangan laki-laki dan budaya Yahudi pada waktu itu.

\section{b) Hak untuk dikasihi}

Perempuan seharusnya mendapatkan perhatian khusus sebagaimana dikatakan di dalam Ef. 5:23 bahwa yang menjadi kepala isteri adalah suami sama seperti Kristus adalah kepala jemaat. Dialah yang menyelamatkan tubuh. Kemudian dilanjutkan Ef. 5:25 "Hai suami, kasihilah isterimu sebagaimana Kristus telah mengasihi jemaat dan telah menyerahkan diri-Nya baginya".

Dari penjelasan teks Kitab di atas perempuan bukanlah lagi kaum yang harus di pinggirkan, dilecehkan, melainkan harus dihormati, dihargai dan dikasihi sama seperti Kristus telah mengasihi semua orang tanpa harus memandang status sosial, pekerjaan, latar belakang, jenis kelamin dan lain-lain. Semua adalah sama di mata Tuhan (perempuan layak untuk dikasihi). Paulus menambahkan bahwa sudah menjadi sifatnya sejak penciptaan apabila seorang istri harus tunduk pada suaminya karena Adam yang pertama diciptakan dan barulah Hawa. Berdasarkan Kejadian 2:21-23, bahwa Hawa diciptakan dari tulang 
rusuk Adam. Implikasi dari kebenaran ini dijelaskan oleh Matthew Henry dalam Rouw and Rouw dengan sangat indah bahwa "Perempuan tidak diciptakan dari kepala Adam untuk dikuasainya, bukan pula dari kaki Adam untuk diinjak-injak olehnya, tapi diambil dari sisi tulang rusuk Adam supaya sama dengannya, dan dekat dengan hatinya untuk dikasihi.(Rouw and Rouw 2019). Semua orang dikasihi oleh Yesus Kristus dan tidak pernah dibeda-bedakan baik laki-laki maupun perempuan. Perhatian-Nya diberikan kepada semua kalangan (Sidauruk 2019: hlm 2). Yesus menghargai keberadaan kaum perempuan sebagai gambar Allah. Prinsip penghargaan secara menyeluruh dan sama secara mendalam diajarkan Yesus tentang mengasihi sesama manusia (Urban 2003: hlm 490).

\section{c). Hak memiliki pekerjaan dan terlibat dalam pelayanan gereja}

Perempuan adalah pribadi yang berperan penting dalam kehidupan. Keberadaan, peran dan kedudukan perempuan merupakan fakta yang tidak terbantahkan. Itulah sebabnya ada slogan yang mengatakan "Di belakang pria sukses ada wanita hebat". Itu sebabnya, tidak berlebihan untuk mengatakan bahwa keberhasilan seorang laki-laki sering sekali ditentukan oleh perempuan yang bersama dirinya.(Siagian, n.d.). Perjanjian Baru mencatat kisah perempuan yang terlibat dalam pelayanan Yesus, bahkan dalam gerakan para rasul di zaman kekristenan mula-mula. Kaum perempuan telah ikut mendukung dan terlibat aktif dalam pelayanan Yesus (Luk. 8:1-3), perempuan terlibat pelayanan di tengah-tengah hubungan yang sudah lama rusak di antara orang Yahudi dan Samaria (Yoh. 4:1-42), perempuan dipilih dan diutus untuk menjadi saksi pertama kebangkitan Yesus (Yoh. 20:11-18). Selanjutnya, perempuan juga terlibat aktif dalam misi bersama para rasul. Oleh karena itulah Paulus juga merasa perlu memberikan salam kepada beberapa perempuan yang terlibat langsung dalam usaha penginjilan (Rm. 16). Perempuan juga hadir sebagai dermawan yang mendukung misi Kristen, bahkan menjadi pelindung yang mengundang komunitas Kristen di dalam rumah mereka.(Siagian 2019: hlm 76)

Lukas menjelaskan di dalam Kisah Para Rasul 17:4,12 bahwa banyak perempuan terkenal akhirnya percaya pada Yesus dan bergabung dengan komunitas yang dibangun Paulus. Para perempuan kaya tersebut akhirnya menjadi terkenal karena mereka membuka rumah mereka untuk berkumpul dan beribadah. Partisipasi kaum perempuan di jemaat rumah itu sangat mendukung perkembangan penginjilan yang dilakukan rasul Paulus. Itulah sebabnya di antara dua puluh lima orang yang dikirimi salam secara pribadi oleh Paulus, dan ada sembilan orang perempuan (Rm. 16). Kesembilan perempuan itu adalah Priskila, Maria, Yunias, Trifena, Trifosa, Persis, ibunya Rufus, Yulia dan saudara perempuan Nereus; disamping nama Febe yang juga disebutkan.(Siagian 2019:hlm 83)

Dari penjelasan di atas maka ada tokoh yang dapat dipelajari yang juga adalah seorang perempuan yang sukses dan percaya kepada Yesus dan yang juga bekerja sama denganNya yaitu: Lidia, dia adalah seorang wanita dari Tiatira, yang tinggal di Filipi dan menjadi murid Paulus yang mula-mula bertobat di Eropa. Ia memberi tumpangan kepada Paulus, bersama Silas dan Lukas (Kis 16:14-15,40). Kata Lidia, dapat merupakan kata sifat yang berarti 'wanita dari Lidia' (nama suku seperti itu adalah umum waktu itu) tapi nama itu juga menjadi nama pribadi (bnd Kis $1: 8 ; 3: 9$ ). Ternyata ia adalah wanita yang menjadi tokoh terkenal (Kis 17:4,12), ia adalah seorang janda yang tidak menikah sehingga ia otomatis juga menjadi kepala rumah tangga. Kain ungu dari Lidia, yang menjadi barang dagangannya sangat terkenal pada waktu itu. Ia seorang penganut agama Yahudi, yang juga terlibat dalam doa-doa dan penyucian pada hari Sabat di tempat di tepi sungai; hubungannya dengan agama Yahudi mungkin berasal dari kontak dengan suatu permukiman di Tiatira. Gereja Kristen telah didirikan di sana, (Wahy 1:11; 2:18-29). Lidia mungkin termasuk dalam kelompok yang menerima salam Paulus di Fili 4:3, tetapi karena namanya tidak disebut mungkin telah meninggal atau telah pindah tempat. Keramah- 
tamahannya menjadi ciri khas yang membuatnya menetap di jemaat Filipi ( Fili 1:5; 4:10).(Ensiklopedia Alkitab Masa Kini 2002:240 ). Menurut Deen, dalam buku All of The Women, Lidia menjalankan bisnisnya di Filipi, sebuah kota di Makedonia. Ia berjalan di jalan-jalan di Filipi menjual kain nilanya. Mungkin dia juga sering memakai baju ungu selagi ia berjalan di jalan-jalan di Filipi. Di Makedonia Lidia dibimbing oleh Paulus dalam kelompok kecil pendoa. Paulus dan Silas berbicara pada para perempuan yang berkumpul disana. Wanita yang menonjol di antara perempuan di situ ialah Lidia, non Yahudi. Karena keingintahuannya tentang keajaiban dan kekuatan dari Tuhan, Lidia ada di tempat doa ini pada hari sabat.(Wassar 2021:32). Bagian diatas ada contoh konkrit tentang hak perempuan yang sudah mulai diakui bahkan kaum perempuan mendapat hak untuk pelayanan di gereja seperti Lidia. Selain dia adalah seorang wanita yang hebat dia juga wanita yang mendedikasikan dirinya untuk melayani Tuhan dan membantu para hamba Tuhan serta membukakan pintu rumahnya bagi Paulus, Lukas dan Silas.

\section{SIMPULAN}

Secara umum perempuan tidaklah mendapat perhatian khusus di dalam hak dan peran serta perlakuan yang baik di dalam masyarakat, apalagi jika dilihat dari budaya Yahudi dan Yunani yang kerap kali menganggap bahwa perempuan adalah kaum yang tidak berdaya dan tidak mempunyai hak serta peran penting dalam kehidupan masyarakat sosial. Di dalam Perjanjian Baru berdasarkan tradisi Talmud, hak-hak perempuan dikurangi sebagai kaum yang lebih rendah, kadang-kadang hanya memiliki peran yang tidak berarti. Tentu kondisi ini tidak sesuai dengan semangat dalam Perjanjian Lama yang mana didalamnya kaum perempuan didorong untuk terjun dalam kehidupan sosial, politik dan keagamaan bangsa Israel.

Di dalam Perjanjian Baru perempuan diakui harkat dan martabatnya, bahkan perempuan menjadi rekan kerja Yesus di sepanjang pelayanan-Nya. Demikian juga dengan Paulus, banyak kaum perempuan yang menjadi partner Rasul Paulus di dalam perjalanan misinya. Di dalam Perjanjian Baru bagi orang Yahudi perempuan adalah kaum yang lemah, tindakan mereka dibatasi, hak kewajiban dan peran mereka juga dikurangi bahkan ironisnya perempuan diperbudak dan diperlakukan secara tidak adil. Yesus hadir di dalam Perjanjian Baru kini telah membawa perubahan yang besar bagi kaum marginal termasuk perempuan di dalamnya. Kini perempuan dibebaskan dari belenggu, sikap diskriminatif, hak dan peran mereka kini berfungsi secara positif dan mereka dapat melayani Tuhan.

Keberhasilan seorang laki-laki, karena ada perempuan yang hebat dibelakanganya yang selalu mendorongnya untuk maju. Mereka adalah pribadi yang sepadan, yang dihadirkan Tuhan sebagai penolong laki-laki. Perempuan yang sering dianggap lemah, tidak berdaya dan kebebasannya dibatasi, kini telah menjadi pemeran utama di dalam karay penebusan Yesus Kristus. Tuhan telah menyatakan kesetaraan laki-laki dan perempuan, semua bentuk diskriminatif, dan kejahatan lainnya terhadap kaum perempuan telah disingkirkan oleh pengajaran Yesus Kristus dan oleh karya penebusan-Nya di kayu salib.

\section{DAFTAR PUSTAKA}

4.30, SABDA (OLD versi Indonesia). n.d. "SABDA (OLD Versi Indonesia) 4.30." Chandra Gunawan. 2014. "Gereja Dan Perubahan Sosial; Perspektif Perjanjian Baru."

Jurnal Tranformasi, 20-22.

Ensiklopedia Alkitab Masa Kini. 2002. Jakarta: Yayasan Komunikasi Bina Kasih. Gunawan, Chandra. 2014a. "Gereja Dan Pembaharuan Sosial.” Sosial, Pembaharuan;

Gereja Dan Pembaharuan Sosial, 10-16. 
—. 2014b. "GEREJA DAN PERUBAHAN SOSIAL: Perspektif Perjanjian Baru." Jurnal Transformasi 10: 1.

Guthrie, Donald. 2008. Teologi Perjanjian Baru 1: Allah, Manusia, Kristus. Terjemahan Lisda Tirtapraja Gamadhi, Dkk. Jakarta: BPK Gunung Mulia. Jakarta: Bpk Gunung Mulia.

Jemali, Maksimilianus. 2018. “Upaya Pastoral Untuk Meningkatkan Peran Kaum.” Jurnal Pendidikan Dan Kebudayaan 10 (2): 204-18.

Lumban Gaol, Berlina. 2014. "Kedudukan Perempuan Dalam Alkitab Dan Masa Kini." Jurnal Transformasi, 14-34.

Merriam, Sharan B. 2009. Qualitative Research, A Guide to Design and Implementation. San Fransisco: Jossey Bass.

Pdt. Drs. Henk Ten Nape. 2006. Jalan Yang Lebih Utama Etika Perjanjian Baru. Jakarta: BPK Gunung Mulia.

Raco, R. 2010. Metode Penelitian Kualitatif, Jenis, Kharakteristik Dan Keunggulannya. Jakarta: Grasindo.

Rouw, Randy Frank, and Julian Frank Rouw. 2019. "Paulus Dan Perempuan.” Jurnal Jaffray 17 (2): 171. https://doi.org/10.25278/jj.v17i2.336.

Selvaraj, Sadhu Sundar. 2001. Perempuan Istimewa Dimata Tuhan. Jakarta: Jesus Ministries.

Siagian, Raulina. n.d. "Transformatif, Perjumpaan Dengan, Yesus," 73-84.

_. 2019. "Perjumpaan Transformatif Yesus Dengan Perempuan.” Jurnal Shanan 3 (1): 73-83.

Siahaya, Nunuk Rinukti. 2018. "Peranan Perempuan Menurut Perjanjian Baru Bagi Perkembangan Kepemimpinan Perempuan Di Dalam Gereja" 1 (1): 33-41.

Sidauruk, Neston. 2019. "Eksistensi Perempuan Dalam Paradigma Dan Pelayanan Yesus." Jurnal Teologi Cultivation 3 (2): 115-26. https://doi.org/10.46965/jtc.v3i2.272.

Urban, Linwood. 2003. Sejarah Ringkas Pemikiran Kristen ,. Jakarta: BPK Gunung Mulia. Wassar, Sarah. 2021. “Tinjauan Teologi Pelayanan Perempuan” 12 (1): 19-32.

Wauran, Queency Christie, Sekolah Tinggi, Filsafat Jaffray, and Makassar Indonesia. 2015. "Perempuan-Perempuan Dalam Kerajaan Baru ( Suatu Perbandingan Eksegesis," no. March 2013: 11-15. https://doi.org/10.13140/RG.2.1.3043.7208.

Wijaya, Elkana Chrisna. 2018. "Eksistensi Wanita Dan Sistem Patriarkat Dalam Konteks Budaya Masyarakat Israel." 